\title{
Empirical Verification of the Accuracy of Valuation Estimates Emanating from Nigerian Valuers: A Case Study of Lagos Metropolis
}

\author{
C.A. Ayedun (Corresponding author) \\ Department of Estate Management, Covenant University, Ota, Ogun State, Nigeria \\ Tel: 234-080-3390-0681 E-mail: caayedun@yahoo.com \\ O.A. Ogunba \\ Department of Estate Management, Obafemi Awolowo University, Ile-Ife, Osun State, Nigeria \\ Tel: 234-080-3401-4739Ｅ-mail: segunogunba@yahoo.com \\ S.A. Oloyede \\ Department of Estate Management, Covenant University, Ota, Ogun State, Nigeria \\ Tel: 234-080-3472-2469 E-mail: samoloye49@yahoo.com
}

\author{
Received: March 7, 2011 Accepted: April 19,2011 Published: November 1, 2011 \\ doi:10.5539/ijms.v3n4p117 URL: http://dx.doi.org/10.5539/ijms.v3n4p117
}

\begin{abstract}
There have been increasing criticisms of the ability of Nigerian valuers to undertake investment valuations in a reliable and accurate manner. This study sought to examine with a view to validating or dispensing the criticisms as to whether Nigerian valuers are capable of undertaking investment valuations in a reliable and accurate manner or not. To achieve this aim, the paper employed quasi-experimental survey methods. Forty five (45) estate surveying and valuation firms were sampled in Lagos Metropolis, the study area. The study used both descriptive and inferential statistics. The study revealed a wide variance of valuation estimates from the sale prices of the twelve properties sampled which indicated that the valuation estimates are not accurate and reliable. The study concluded that the Nigerian Institution of Estate Surveyors and Valuers and Estate Surveyors and Valuation Registration Board of Nigeria (the two bodies responsible for the regulation of the valuation profession in the country) should take up the responsibility of ensuring that variance in valuation is minimised by way of providing databank in order to provide more meaningful valuation advice.
\end{abstract}

Keywords: Valuation accuracy, Variance, Reliability, Lagos Metropolis, Nigeria

\section{Introduction}

In the absence of continuously traded, deep and securitised markets, property valuations perform a vital function in the property market by acting as a surrogate for transaction prices. As with asset prices in the equity market and bond markets, property asset valuations are central to the inter-related processes of performance measurement, acquisition and disposal decisions. However, within both the professional and academic communities there is considerable scepticism about the professional ability of valuers to fulfil this role in a reliable manner.

Researchers in the major Commonwealth markets (UK, Australia and Nigeria) as well as the US, have in the past twenty-five years or thereabout has been investigating into the degree to which valuations provide acceptable predictions of realized price and valuations of other firms. In the process of these researches, the concept 'valuation accuracy' has become topical. Valuation accuracy is the measure of the difference between prior valuations in relation to subsequently realized sales prices. Several studies have also focused on the related term 'valuation variance'. Variance is essentially a theoretical measure used to indicate the reliability of valuations, expressed as the distribution of valuations around the mean or median valuation that would result if a number of valuers valued the same property simultaneously (Havard, 2001). 
Debates on the accuracy and variance of valuations have been very topical since the 1980s and 1990s in the UK, US, Australia and are increasingly becoming popular in emerging countries as Nigeria. A number of reasons have prompted the present re-examination of question of accuracy in the country. Basically this arises out of the fact that the accuracy/variance debate has been inconclusive both in the UK and in Nigeria. In the UK there have been contradictory findings on accuracy/variance over the years. Researchers such as Hager \& Lord (1985), Matysiak and Wang (1995) and Hutchison et al (1995) have found that valuations are inaccurate and inconsistent (especially if one adopts a maximum margin of error of $+/-10 \%$ ), while authors such as Brown (1985), IPD/Drivers Jonas (1988, 1996 and 2004), and Mokrane, (2002) felt otherwise. The difference appears dependent on the statistical methodology employed. Whilst most of the high accuracy/variation advocates employed regression based procedures, most of the low accuracy/variation advocates employed mean/standard deviations. The inconclusive nature of the results has been exuberated by methodological problems in the empirical studies carried out.

In Nigeria, there have also been contradictory accuracy/variance findings. Papers such as Ogunba $(1997,2003)$ found a high degree of inaccuracy and inconsistency in valuations while the Aluko (2000) study suggests a fairly high level of accuracy. To ascertain the causes of inaccurate and inconsistency which had been established from the valuation estimates emanating from Nigerian valuers, the paper therefore examined the choice of valuation inputs being applied by the valuers in the country.

In addressing this aim, the paper is structured into five sections. The first is introductory. The second section focuses on the literature review. The third section provides information on the study area (Lagos state in Nigeria), while section four discusses the research method. In section five, the paper discusses the results from empirical investigations while section six provides recommendations and concluding comments.

\section{Review of Related Literature}

In the UK, the valuation accuracy (or inaccuracy) debate was triggered off by Hager and Lord (1985)'s work wherein they conducted a small sample survey of ten Surveyors who were invited to value two properties. In one case the range of valuations was $+/-10.6 \%$ and in the other, it was $+/-18.5 \%$ suggesting a relatively low level of valuation accuracy relative to the $+/-5 \%$ benchmark adopted.

Brown (1985) conducted a larger and much more rigorous study on a sample of 29 properties for which there were transaction prices and recent prior valuation figures. In the study, independent valuation firms were made to carry out the valuations of the subject properties. Both valuations and sale transactions took place between 1975 and 1980. In addition, both the valuations and the sale transactions were based on the RICS definition of Open Market value, which excludes special purchases, forced sales etc. The author used regression analysis to compare valuation estimates and sale prices on the 29 sampled properties.

IPD/Drivers Jonas (1988) also adopted a regression based procedure, but made use of a much larger sample size of 1,442 properties, all of which were sold between January 1982 and March 1988. Each of these properties had at least two (2) open market valuations prepared in respect of them in the two consecutive years preceding their sales, with all the valuations undertaken between January 1980 and December 1987. They analysed these samples with the inverse of the Brown (1985) procedure (the least square model regressed price on value). This study also found a high correlation of $93.4 \%$ between valuation estimates and transaction prices $\left(\mathrm{R}^{2}=93\right)$ suggesting a high level of valuation accuracy.

In 1990, IPD/DJ updated their study with a larger analysis of 2,400 properties for which there were transaction sales figures and valuation estimates. The study still observed high correlations between valuation estimates and sale prices as earlier found in their 1988 study, thus further supporting an UK (IPD/DJ, 1990) study. However, Lizieri and Vienmore-Rowland (1991) questioned the regression based statistical methodology adopted by IPD/Drivers Jonas and Brown for their studies drawing attention to its inherent flaws (a problem known as heteroascidity). Despite this criticism, IPD and Driver Jonas continuously updated their regression based studies every other years 994, 1996, and lately 2004 with increased sample sizes, analysis period and range of statistical analyses employed. Results obtained consistently maintained the same basic findings concerning high levels of valuation accuracy. The Lizieri and Venmore-Rowland (1991) criticism exposed the statistical validity of studies of the IPD/DJ which employed simple regression analysis to find high levels of valuation accuracy (see, for example, Brown, 1992). In the same way, the potential role of behavioural research in the determination of valuation accuracy debate has been suggested to questioning too (Waldy, 1997).

Matysiak and Wang (1995) employed standard deviations in their analysis of 317 sets of valuation estimates and transaction prices data covering the period of 1973 to 1991 . Following the extensive statistical discussions and manipulations, the authors found that the probability of achieving a selling price within $+/-10 \%$ of the valuation 
estimate was only $30 \%$, rising to a probability of $55 \%$ within $+/-15 \%$ of the valuation and $70 \%$ within $+/-20 \%$ of the valuation estimates. The authors also went on to examine the propensity of valuers to overvalue in falling markets and undervalue in rising markets. The study noted that "......given the indicative evidence for the significant impact of the bull/bear market environments in conditioning the valuation figures, more analysis is required in eliciting the relationship between valuer's behaviour and changing market conditions" (Matysiak and Wang, 1995). However, whilst the Matysiak and Wang (1995) findings would appear to undermine those of other studies concerning high levels of valuation accuracy relative to transaction sales, the complexity of the statistical analyses adopted renders a full appreciation of the findings challenging as not too many people can handle some of the statistical tools employed in their study.

Hutchison et al (1995) surveyed five national valuers and five local valuers for each of 14 centres in UK, seeking valuations at no fee for a range of hypothetical retail, office and industrial buildings with particular characteristics in actual locations and with standard leases. Valuation variation (consistency) rather than accuracy (reliability) was examined. They found differences in the variance of valuation between national and local valuation firms $(8.63 \%$ and $11.86 \%$ respectively for national and local firms). The authors discovered that over $80 \%$ of all the valuations produced a variation from the mean of less than $20 \%$, which is a wider valuation variation than that suggested by Brown's (1991) earlier study.

Mokrane (2002) addressed the twin issues of valuation accuracy and consistency in five European countries (UK, France, Sweden, Netherlands and Germany). In these countries, he considered time periods of 1990 to 2000 in UK; 2,000 properties over the period of 1999 to 2000 in France; 1,800 properties over the period of 1997 to 2000 of Sweden; 5,700 properties over the period of 1999 to 2000 in Netherlands; and 400 properties over the period of 1997 to 2000 in Germany. The accuracy tests made provision for the adjustment of previous valuation for market movements and capital expenditures and receipts that may have taken place between the valuation date and transaction date. With regards to accuracy, he came up with conclusions that there exists only a short "distance" between transaction sales and adjusted valuations in the respective countries, though valuation estimates differed from sale prices. With regards to consistency, he found that in most of these countries, the degree of variation was low and the change-in-valuer effect was statistically significant.

Bretten and Wyatt (2002) investigated the extent and possible causes of variance in property investment valuation for commercial lending purposes within UK using questionnaire survey circulated to 220 lenders, finance brokers, valuers, property companies and institutional investors involved in commercial property valuation process in order to gauge professional opinion. They observed that the main cause of variance was the individual valuer's "behavioral influences" and that parties to a valuation instruction widely accept "the margin of error" principle. Their study concluded that variance can enter the valuation process at any stage, from the issuing of instruction letters and negotiation of fees through to external pressure being exerted on the valuer when finalizing the valuation figure. Although the study circulated to 220 individuals involved in the commercial property valuation process, they however did not involve the court officials. This study considered this very necessary and involved 6 court officials (5 judges and one court registrar) in addition to other individuals involved in the commercial property valuation process. In addition, their survey failed to recognize the need for the use of real life valuation and sale figures and for this reason, this study made use of valuation and sale figures of 131 real life recently valued and sold properties in addition to the valuation of 12 selected properties valued by 45 valuers.

Crosby, Devaney, Key and Matysiak (2003) identified whether the 2002 sales in the IPD Monthly index threw any light on whether the sale price was known before the completion date or if in their study of timing of the valuation and sale data in UK uses valuations and sales data from the sale was agreed before completion date. The study concluded that timing issues had been identified as one of the technical difficulties in producing definitive results on differences between prices and valuations.

Generally, as earlier noted, the UK review shows that there have been contradictory findings over the years. Researchers such as Hager \& Lord (1985), Matysiak and Wang (1995) and Hutchison et al (1995) seem to suggest that valuations are inaccurate and inconsistent (especially if one adopts a maximum margin of error of +/-5- 10\%), while authors such as Brown (1985), IPD (1988, 1990, 1992, 1994, 1996, 2004), and Mokrane, (2002) felt otherwise. The difference appears dependent on the statistical methodology employed. Whilst the high accuracy/variation advocates employed regression based procedures, the low accuracy/variation advocates employed mean/standard deviations. There are also heteroascidity problems with the regression based procedure and the problem of an acceptable maximum bracket of error with the standard deviation approach. 
Armitage and Skitmore (2003) undertook a study on property market analysis in the valuation process with acknowledgement to valuation reporting. The study revealed from informal interviews with clients/users of valuation reports that there was rather over emphasis on the descriptive components of the valuation reports at the expense of of analytical aspects of the valuation works which was an indication that the clients were more interested in seeing the analyses of their properties being valued than the descriptive aspect which the valuers often pay more attention to.

Crosby et al (2004)'s study focused on three stakeholders of valuation estimates namely commercial lenders, commercial and residential valuers. Both the commercial lenders and valuers were of the opinion that valuation reports ought to include the valuer's calculations, assumptions made and details of comparable properties used at arriving at the figures being recommended to the clients. The lender groups especially required more contextual and interpretative information, to assist them in their understanding of the valuation figures and were more critical of some valuers who often overload their valuation reports with what they described as mere standardised information on the property market generally but fail to provide tailored or requested information Conclusively, the lenders professed general satisfaction with valuation reports emanating from valuers in the UK but expressed their dissatisfaction with the levels of analysis and interpretation of the valuation reports.

Newell (2005) a study carried out in 2004 established the increase in the use of Discounted Cash Flow (DCF) analysis in preference to the investment method of valuation and the fact that a greater number of clients tend to prefer the DCF analysis to the conventional method of valuation as represented by investment method. The study further revealed concern over the failure to understand the complexities and market position under the conventional method of valuation and the need for a greater emphasis on the current supply and demand situations in the property markets.

In Nigeria, Ogunba (1997) undertook an empirical step at addressing the question of accuracy and variance in investment valuations in Nigeria using Lagos metropolis as the study area. In the absence of a database of property valuations and sales, he resorted to the approach of requesting thirty Lagos based practicing estate surveying and valuation firms to carry out valuations of two residential properties earlier sold located at Victoria Island and Ikoyi respectively. The valuation estimates subsequently arrived at by the valuers was subjected to a number of statistical tests such as range, inter-quartile range, mean deviation and regression/correlation analysis. The result of the statistical tests showed that valuations were not a good proxy for market prices, for three reasons. First, the average variance between valuations and prices was far in excess of his adopted margin of error of $+/-5 \%$; the intercept in the regression equation was statistically distinguishable from zero and the slope statistically distinguishable from 1; and third, the range and inter-quartile ranges were unacceptably wide. The results of the study must be interpreted with caution because only two (2) properties were considered (as in the Hager and Lord, 1985 study) and the sample of valuers (thirty firms) was small.

Aluko (2000) carried out an accuracy study on a larger scale with a focus on mortgage valuations and subsequent sale prices of foreclosed mortgage properties. In his study, Bank records of mortgage valuations conducted by fifty nine (59) estate firms in Lagos metropolis were examined. The sale prices of the properties were compared with their earlier valuation estimates and analyzed by means of regression/ANOVA. He came to a conclusion that valuations in Nigeria are a good proxy for price and that despite the anecdotal evidence to the contrary the mortgage valuers are doing a very good job of price prediction. However, even though the study sample size is larger than that in Ogunba and Ajayi (1998) study, and even though the study overcame the problem of valuers not inspecting properties and not being paid, the sale prices of collaterized properties adopted for cross-checking the result of the prior valuations were likely to be forced sale values which do not meet the definition of open market value in terms of time on the market. Finally, the study did not consider the time lags between the dates when the properties were valued and the dates such properties were eventually sold.

Ogunba (2003) expanded the coverage area of accuracy studies to a consideration of property valuation estimates and sale prices in the six states of south-western Nigeria. The approach adopted in the study was similar to the one adopted in his earlier work. A total of 171 estate surveying and valuation firms which constituted $75 \%$ of the sample frame of estate surveying and valuation firms in Southwestern Nigeria were employed for the study. Statistical tests such as range, inter-quartile range, mean deviation, regression analysis, and analysis of variance employed by the author confirmed his earlier work that valuation estimates were not good proxy for sale prices and also that valuation estimates of one firm were not good proxy of other firms. The study also extended to an examination of the causes of valuation inaccuracy under topics such as the conduct of valuations, and the educational and practice structure of the valuation industry. 
Ogunba and Iroham (2008) addressed the recurrent problem of identifying the accuracy/consistency benchmark (a maximum acceptable margin of error), beyond which valuations should be considered negligent. This has been a problem with the use of standard deviations in accuracy research. Their work aimed at discovering such a margin of error perceptually in the Nigerian context (for stable market conditions) from the view points of both valuers and their clients. The research method involved the distribution of questionnaires to 195 estate surveyors and valuers in Lagos metropolis, and all the 25 commercial banks in the country. The perceptual responses demonstrated that the benchmark for valuation variance in Nigeria could range between $\pm 11.1 \%$ (as suggested by valuers) and $\pm 13.16 \%$ (as suggested by their mortgage valuation clients). It was noted that the appropriate implementation of such a margin of consistency in unstable market conditions must be cautious and flexible, taking into consideration the availability of data.

The above Nigerian literature points to the inconclusive and even contradictory nature of accuracy/variation research. The problem is exuberated by methodological problems. The earlier studies are plagued with problems of researchers of comparing prior valuation estimates with sale prices of properties suspected of being forced sale values and values suspected of being influenced by lagging. Moreover the employment of a margin of error of $\pm 5 \%$ by Ogunba in his 1997 study and $\pm 10 \%$ employed in his later study of 2003 may have been too stringent as Iroham and Ogunba (2008) suggested a margin of error of up to $\pm 13.16 \%$ as acceptable to clients. There is therefore the need for new empirical investigation that takes this into account.

\section{The Study Area}

Lagos State (Figure 1) covers an area of about 3,577 square kilometers, representing $0.4 \%$ of Nigeria's territorial landmass according to Esubiyi (1994). The State shares boundary in the North with Ogun State, West with the Republic of Benin, and stretches for over 180 kilometers North of the Guinea Coast of the Atlantic Ocean. Politically, Lagos State according to Ogunba (1997) had expanded as a result of rural-urban drift and had become a metropolis enclosing settlements such as Mushin, Oshodi, Ikeja, Agege, Shomolu and Bariga. The 2006 National census put the population of the State at 9,013,534.

Lagos Metropolis has been chosen as the study area because it is the most important commercial city in Nigeria thus providing a sufficiently vibrant economic base and valuation activity which the researcher hopes to provide a vigorous and robust study base. Lagos metropolis, apart from being Nigeria's former capital, is the largest metropolitan city in Africa. The metropolis is located within the coastal frontage of Lagos State and is bounded in the West, by the Republic of Benin, in the East by Ondo State and Atlantic Ocean in the South and in the North by Ogun State. The metropolis covers an approximate land area of 2,350 square kilometers spreading over four main islands of Lagos, Iddo, Ikoyi and Victoria islands.

Also Aluko (2007) carried out further study of the mortgage valuation process in Lagos metropolis. In the study, the author administered questionnaires randomly on Estate Surveying and Valuation firms practising within the study area as well as the lending institutions with the intention of ascertaining whether the contents of mortgage valuation reports and estimates being given by the valuers meet the expectations of the lending institutions as well as meeting the standards set for such valuation by the profession. The report of the study revealed that mortgage valuation reports emanating from the valuers did not meet the needs and demands of the clients as represented by the lending institutions sampled.

In the economic scene, Lagos metropolis has grown from a small farming and fishing settlement to become an important centre of commerce, finance and maritime in Nigeria, housing the headquarters of several banks, industries and commercial enterprises. According to the NIESV Directory (2009), most Estate Surveyors and Valuers aggregate around major business districts of the metropolis such as Lagos Island, Ikeja, Apapa/Ijora, and Lagos Mainland where there is the expectation of a very active property market.

\section{The Research Methods}

The research study population comprise of the estate surveying and valuation firms in Lagos Metropolis which has over fifty (50) percent headquarters of such firms operating in Nigeria according to the directory of the Nigerian Institution of Estate Surveyors and Valuers (2009). All the firms are registered with Estate Surveyors and Valuers Registration Board of Nigeria (ESVARBON) which is the only body legally empowered to register and regulate estate surveying and valuation practices in the country. The study adopted four nuclei in the stratification of Lagos Metropolis (the study area). This is borne out of the fact that the study population is found aggregating around these economic nuclei where there is the expectation of very active property market, easy accessibility and complementarity advantages. The study employed quasi-experimental and the survey methods towards achieving the objective of the study. The experiment was carried out using an observed simulated valuation of twelve (12) residential properties all of which were sold within a period of one to two months to the 
dates the valuation were carried out by expert valuers. Simulated valuation experiments consisted of an observed, simulated valuations of twelve residential properties which were sold within one to two months to the dates of valuation exercise as noted above. The information regarding the sale prices of the properties were not disclosed to the valuers involved in the simulated valuation exercise.

The simulated valuations were carried out in the offices of the respondents using the data supplied them by the author. The subjects of the valuation consisted of twelve (12) residential properties (Table 1 show summary details about the 12 sampled properties) located variously within different parts of Lagos Metropolis where all the valuers involved in the valuation exercise were practising. All the participants received the same materials in the same order and produced valuation estimates at the end of the process. The valuers were provided with the descriptions and locations of the properties to enable them carry out the valuation of the properties. The fact that each of the valuers received the same set of information is critical and essential as the experiment is intended to ascertain how accurate and reliable the valuers are at predicting the sale prices of properties intended for sale.Also, the survey equally employed the use of self-administered questionnaire to obtain relevant data from participating valuers. This is with a view to ascertaining their level of competence and experience in the practice of valuation assignments. Forty five (45) estate surveying and valuation firms were sampled. Stratified sampling method was adopted for selecting the sampled valuers from the four nuclei geographical locations earlier identified. Data obtained were analysed with the use of both descriptive and inferential statistical analyses.

\section{The Results}

The results from analyses of the valuation of the 12 simulated properties carried out by the forty five (45) respondent valuers with a view to ascertaining the accuracy level of valuation estimates emanating from the valuers vis-à-vis the sale prices of the properties are as presented in Tables 2, 3 and 4 (see appendix). The result of the analysis of the valuation estimates vis-à-vis the sale prices of the 12 sampled properties carried out by the valuers contained in the Table 2 showed very wide ranges of disparities between the sale prices of the sampled properties and valuation estimates which produced a difference of up to Six hundred (\$690) million naira Nigerian money in the case of property 9. Even where one cuts off the extreme values (the overvalued and undervalued half of valuations), the range of valuations is still extremely high for example, up to $\$ 58.5$ million in the case of property 9 when inter-quartile range analysis is employed is still very much far from being accurate. The standard and mean deviations equally revealed a high level of inaccuracy. None of the mean values fell within thirty (30) per cent of the selling prices. The mean deviation from market price for all the sampled properties came to $\pm 32.44 \%$. This represents a very high degree of inaccuracy relative to the $\pm 5 \%$ adopted by Hager and Lord (1985) study. This means that valuers in the study area are not in any way interpreting market prices with any appreciable degree of accuracy. The study also sought to ascertain the number of valuers who were able to conduct valuations within different ranges of error. The results are documented in Table 3 . The results as documented in Table 3 indicated that only $4.4 \%$ of the valuation estimates tallied with the sale prices of the properties while $8.3 \%$ of the valuation fell within the range of $\pm 5 \%$ margin of error while $15.2 \%$ of the valuations fell within the margin of error of $\pm 10 \%$ range. If $\pm 10 \%$ variance is taking to be acceptable margin of error as is the case with some advanced countries such as Britain, that mean only $15.2 \%$ of the valuation estimates fall within the acceptable margin of error in this study and this is a far cry from $90 \%$ achieved by Baum et al in 2000 and even 59\% achieved in their earlier study carried out far back in 1983 according to Baum (2000).

Table 4 further revealed the performances of the respondent participant valuers by showing the differences (disparities) between the valuation estimates and the sale (transaction) prices of each of the properties. The figures contained in the table are the differences between the valuation figures and the sale prices which were arrived at after deducting the valuation figures of each of the valuers from the sale prices (i.e. sale/transaction prices - valuation estimates) for each of the twelve properties. The figures with negative (-) signs are the figures/differences by which the valuation estimates exceeded the sale prices while the figures without any negative/positive signs are those figures from the valuation estimates which were either lower or higher than the sale prices. On the other hand, the zero (0) figures indicate that both the valuation figures and sale prices were equal to each other hence such valuation estimates were regarded to be $100 \%$ accurate.

A cursory look at the figures in the table showed that the differences in the valuation figures and sale prices are very significant and alarming which is an indication that the valuation estimates emanating from the professional estate surveyors and valuers in Nigeria are very far from being accurate and as such cannot be relied upon for sale measurement. A situation by which the differences between valuation and sale price is going as high as more $\pm 50 \%$ cannot be described as ideal and would therefore need an urgent attention. 


\section{Conclusion and Recommendation}

Based on the analysis of valuations and sale prices of the twelve simulated properties, there is strong evidence to conclude that Nigerian valuers valuation estimates cannot be described as good proxy for market sale prices. This gives reason for concern, especially since the valuation estimates emanating from them were very far from the sale prices of the properties. In a situation where only $15.2 \%$ of the valuation estimates fall within $\pm 10 \%$ margin of error cannot be regarded as good performance. This represents unacceptably high degree of inaccuracy relative to $90 \%$ achieved by Baum et al in 2000 and even $59 \%$ achieved in their earlier study carried out far back in 1983 according to Baum et al (2000). The implication of this is that valuers in Lagos are not interpreting their markets with anything close to accuracy of valuers in such developed economy like Britain. Certainly, an opportunity for further research would involve investigating into reasons for the marked disparity.

One main implication drawn from this paper is the need to stem the unusually high level of inaccuracy. The Nigerian valuation regulatory bodies: the Nigerian Institution of Estate Surveyors and Valuers and the Estate Surveyors and Valuers Registration Board of Nigeria would need to take a number of urgent corrective actions. Such corrective actions are not part of the objectives of this paper and accordingly have not been discussed, but a number of useful actions have been suggested in recent Nigerian literature. First, Oloyede and Ayedun (2009) and Iroham and Ogunba (2008) have suggested that a mandatory maximum margin of error of $\pm 13.2 \%$ should be enforced for stable market conditions beyond which valuers should be considered negligent. This may be necessary because once a valuer is aware of the existence of such accuracy benchmarks; he would be more inclined to undertake serious market study and less inclined to hide under the cloak of a valuation estimate being an opinion of value. A second direction of corrective action has to do with more rigorous training of valuers with a view to minimising the incidences of unreliability and inconsistency of investment valuation in the country (Ogunba and Ojo (2007). Third, there should be the enforcement of the use of valuation standards.

More importantly, this study has brought to the fore the inadequacy of valuation opinions being given by the Nigerian valuers and the need by the profession to do something about the issue. The Nigerian Institution of Estate Surveyors and Valuers should as a matter of urgency set up a quality control committee that will undertake a regular assessment of the accuracy of valuation figures.

Moreover, in order to reduce the level of valuation inaccuracy by the Nigerian valuers, the profession has to improve on its lay down valuation standards for sale/purchase purposes and probably for other purpose too. The improve standards should cover areas such as bases, methods and procedure of valuation. The Guidance Notes on Property Valuation should be subject to regular updating and review to allow for improvement and compliance with what obtain internationally. Failure to address these inherent issues could pose a serious threat to the credibility and integrity of valuers and even damage the public image of the estate surveying and valuation profession in the country. This could also lead to the profession being obsolete and encourage incursion of other professionals into its core area of the Estate Management profession. Already, there is an existing attempt by professionals such as the Quantity Surveyors, Engineers and Accountants, to make in-roads into the valuation profession. This may lead to a substantial of loss of business for many valuers as clients may start looking for other means of appraising their property values. This may also increase the valuer's exposure to claim for negligence.

To assist the practising estate surveying and valuation firms in the country, the institution should as a matter of urgency establish a data bank in order to provide important valuation inputs for the valuers in the country so as achieve tolerable valuation masrgin of error.

The study is carried out in Lagos metropolis which constitutes the economic and industrial hub of the country, however, to give the study a national outlook, similar studies can be carried out to cut across other urban centres in the country.

\section{References}

Aluko, B.T. (2000). A Study of Appropriateness of Mortgage Valuation for Institutional Lending in Nigeria. Unpublished PhD Thesis Submitted to the Department of Estate Management, Obafemi Awolowo University, Ile-Ife; Nigeria.

Aluko, B.T. (2007). Implications of the Current Trends in Mortgage Valuation Practice in Nigeria. International Journal of Strategic Property Managemet.

Armitage, L., and Skitmore, R.M. (2003). Property Market Analysis in the Valuation Process: A Survey of Australian Practice. Pacific Rim Property Research Journal, 9 (4), 330-347. 
Baum, A., Crosby, N., Gallimore, P., Gray, A., and McAllister, P. (2000). The Influence of Values and Valuations on the Workings of Commercial Investment Market. London, IPF/RICS Research Founation/Jones Landsalle.

Bretten, J., and Wyatt, P. (2002). Variance in Property Valuations for Commercial Lending, Vol. 4, No. 9. RICS Foundation May 2002 Electronic Reference PS0409. [Online] Available: http://www.rics-foundation.org

Brown, G. (1985). Property Investment and Performance Measurement: A Reply. Journal of Valuation, Vol. 4, pp 33-44. http://dx.doi.org/10.1108/eb007986

Brown, G. (1992). Valuation Accuracy: Developing the Economic Issues. Journal of Property Research, Vol. 9 , pp 199-207. http://dx.doi.org/10.1080/09599919208724067

Crosby, N., Hughes, C., and Murdoch, J. (2004). Influence on Secured Lending Property Valuations in the UK. Paper Presented at the 11th European Real Estate Society Conference.

Crosby, N., Devaney, S., Key, T., and Matysiak, G. (2003). Valuation Accuracy Reconciling Timing of the Valuation and Sale. European Real Estate Society, Helsinki-Finland.

Esubiyi, A.O. (1994). Obsolescence and Property Values: A Case Study of Lagos. Unpublished B.Sc Dissertation Submitted to the Derpartment of Estate Management, Obafemi Awolowo University, Ile-Ife, Osun State Nigeria.

Hager, D.P., and Lord, D.J. (1985). The Property Market, Property Valuations and Performance Measurement. Institute Of Actuaries, London.

Hutchison, N., Macgregor, B., and Nanthakumaran, N. (1995). Variations In The Capital Valuations Of UK Commercial Property: Do Valuers Get It Right? RICS 1995 Cutting Edge Conference, Aberdeen, September.

IPD/DJ (1988). The Variance In Valuations. Drivers Jonas, London.

IPD/DJ (1996). The Variance In Valuations 1996 Update. Drivers Jonas, London IPD/DJ.

IPD/DJ (2004). The Variance In Valuations 2004 Update. Drivers Jonas, London.

Iroham, O. C., \& Ogunba, O. A. (2008). The Search for an Acceptable Maximum Margin of Valuation Error: The Nigerian Position. The Estate Surveyor \& Valuer. Journal of the Nigerian Institution of Estate Surveyors and Valuers. Lagos, March 2009.

Lizieri, C., and Vienmore-Rowland, P. (1991). Valuation Accuracy: A Contribution to the Debate. Journal of Property Research.

Matysiak, G., \& Wang, P. (1995). Commercial Property Market Prices and Valuations: Analyzing the Correspondence. Journal of Property Research.

McAllister, P. (1995). Valuation Accuracy: A Contribution to the Debate. Journal of Property Research, Vol.12 (3), pp.181-202. http://dx.doi.org/10.1080/09599919508724145

Mokrane, M. (2002). Valuations: Standards, Accuracy and Consistency. IPD European Property Strategies Conference, May, 2002, pp.20.

Newell, G. (2005). Client Perception of the Quality of Valuatio Reports in Australia. Pacific Rim Property Research Journal, Vol. 10, No. 4, 437-450.

NIESV Directory. (2009). The Directory of the Estate Surveyors and Valuers. The Official Publication of the Nigerian Estate Surveyors and Valuers.

Ogunba, O.A., and Ajayi, C.A. (1998). An Assessment of the Accuracy of Valuations in the Residential Property Market of Lagos. A Journal of the Nigerian Institution of Estate Surveyors and Valuers, Vol.21, No.2, Pg.19-23.

Ogunba, O.A. (1997). A Study of Valuation and Pricing Methods in the Residential Property Market In Lagos Metropolis. An Unpublished M.SC. Dissertation Submitted to the Department of Estate Management, Obafemi Awolowo University, Ile Ife.

Ogunba, O.A. (2003). Implementation Hurdles in the Search for Rationality in Investment Valuation in Nigeria. Journal of Property Research and Construction, (1), 14-28.

Ogunba, O.A., and Ojo, O. (2007). Reliability, Consistency and Rationality of Professionally Prepared Valuations: Suggestions for Resolving the Problems in Nigeria Practice. A Paper presented at the 2004/2005 CPD Training Workshop on Asset Valuation Organized by The Nigerian Institution of Estate Surveyors and Valuers and holding in Lagos, Kaduna and Enugu. 
Oloyede, S.A., and Ayedun, C.A. (2009). Estate Surveyors and Valuers: Value Inventors or Assessors? Journal of the Nigerian Estate Surveyors and Valuers, Vol. 31, No. 2, July to December.

Reid, I. (1985). A Response To Hager and Lord. Estate Gazette, 2714, 19-21.

Waldy, B. (1997). Valuation Accuracy 64th FIG Permanent committee Meeting and International Symposium, Singapore, May.

Table 1. Summary Details of 12 Sampled Properties

\begin{tabular}{|c|c|c|c|c|}
\hline $\mathbf{S} / \mathbf{N}$ & Properties & $\begin{array}{l}\text { Sale Prices } \\
(000,000) \\
(=\mathbf{N}=)\end{array}$ & $\begin{array}{c}\text { Location } \\
\text { of Properties }\end{array}$ & $\begin{array}{l}\text { Description of } \\
\text { Properties }\end{array}$ \\
\hline 1 & Property 1 & 200 & Ikoyi & $\begin{array}{l}\text { 5-bedroom Detached House; } \\
\text { 2-bedroom Guest Chalet plus } \\
\text { 2-room BQ on } 2644 \text { sq. mts }\end{array}$ \\
\hline 2 & Property 2 & 20 & Ojodu & $\begin{array}{c}\text { 5-Bedroom detached House; } \\
\text { 2-room BQ and Security House } \\
\text { on } 821.74 \text { sq. mts }\end{array}$ \\
\hline 3 & Property 3 & 18 & Ojodu & $\begin{array}{l}\text { 3-Storey block of 6No. 3-bedroom } \\
\text { flats built on } 684.30 \text { sq. mts }\end{array}$ \\
\hline 4 & Property 4 & 35 & $\begin{array}{l}\text { Amuwo-Odofin } \\
\text { Residential Housing } \\
\text { Estate, Ojo }\end{array}$ & $\begin{array}{l}\text { 4-Bedroom Detached House } \\
\text { on } 600 \text { sq. } \mathrm{mts}\end{array}$ \\
\hline 5 & Property 5 & 26 & $\begin{array}{l}\text { Amuwo-Odofin } \\
\text { Residential Housing } \\
\text { Estate, Ojo }\end{array}$ & $\begin{array}{l}\text { 4-Bedroom Semi-Detached House } \\
\text { on } 720 \text { sq. } \mathrm{mts}\end{array}$ \\
\hline 6 & Property 6 & 20 & $\begin{array}{l}\text { Amuwo-Odofin } \\
\text { Residential Housing } \\
\text { Estate, Ojo }\end{array}$ & $\begin{array}{l}\text { 3-Bedroom Terrace House } \\
\text { on } 240 \text { sq. } \mathrm{mts}\end{array}$ \\
\hline 7 & Property 7 & 65 & Lekki & $\begin{array}{l}\text { 4-Bedroom Terrace House } \\
\text { on } 700 \text { square } \mathrm{mts}\end{array}$ \\
\hline 8 & Property 8 & 55 & Lekki & $\begin{array}{l}\text { 4-Bedroom Semi-Detached House } \\
\text { on } 600 \text { sq. } \mathrm{mts}\end{array}$ \\
\hline 9 & Property 9 & 180 & Lekki & $\begin{array}{l}\text { A block } 6 \text { No. } 3 \text {-Bedroom } \\
\text { on } 600 \text { sq. } \mathrm{mts}\end{array}$ \\
\hline 10 & Property 10 & 2.5 & $\begin{array}{c}\text { Ojokoro, } \\
\text { Lagos/Abeokuta Road }\end{array}$ & $\begin{array}{l}\text { 2-Bedroom flat located on the first } \\
\text { floor in a block of } 6 \text { No. flats within } \\
\text { Ojokoro Housing Estate. }\end{array}$ \\
\hline 11 & Property 11 & 3 & $\begin{array}{c}\text { Ojokoro, } \\
\text { Lagos/Abeokuta Road }\end{array}$ & $\begin{array}{l}\text { 3-Bedroom flat located on the first } \\
\text { floor in a block of } 8 \text { No. flats within } \\
\text { Ojokoro Housing Estate. }\end{array}$ \\
\hline 12 & Property 12 & 52 & Ogba, Ikeja & $\begin{array}{l}\text { A block of 4No. 4-Bedroom flats } \\
\text { located within Ijaiye Medium } \\
\text { Income Housing Estate at Ogba, } \\
\text { Ikeja; Lagos State. }\end{array}$ \\
\hline
\end{tabular}


Table 2. Assessment of the Accuracy of Sampled Properties by Means of Several Tests

\begin{tabular}{|c|c|c|c|c|c|c|}
\hline \multirow[b]{2}{*}{ Properties } & \multirow{2}{*}{$\begin{array}{c}\text { Sale } \\
\text { Prices } \\
(000,000) \\
\end{array}$} & \multicolumn{5}{|c|}{ Results of the Statistical Tests } \\
\hline & & $\begin{array}{c}\text { No. of } \\
\text { Valuers }\end{array}$ & $\begin{array}{c}\text { Range } \\
(000,000)\end{array}$ & $\begin{array}{c}\text { Inter-qua } \\
\text { rtile } \\
\text { Range } \\
(\mathbf{0 0 0 , 0 0 0 )}\end{array}$ & $\begin{array}{c}\text { Mean Deviation } \\
(000,000)\end{array}$ & $\begin{array}{c}\text { Std Deviation } \\
(\mathbf{0 0 0 , 0 0 0 )}\end{array}$ \\
\hline $\mathbf{A}$ & $\mathbf{B}$ & $\mathbf{C}$ & D & $\mathbf{E}$ & $\mathbf{F}$ & $\mathbf{G}$ \\
\hline Property 1 & 200 & 45 & 550 & 80 & $\begin{array}{c}98.9 \\
(49.5 \%)\end{array}$ & $\begin{array}{c}115.20 \\
(57.6 \%)\end{array}$ \\
\hline Property 2 & 20 & 45 & 91 & 9.75 & $\begin{array}{c}14.04 \\
(70.2 \%)\end{array}$ & $\begin{array}{l}18.40 \\
(92 \%)\end{array}$ \\
\hline Property 3 & 18 & 45 & 170 & 8.5 & $\begin{array}{c}17.80 \\
(98.8 \%)\end{array}$ & $\begin{array}{c}25.90 \\
(144 \%)\end{array}$ \\
\hline Property 4 & 35 & 45 & 77 & 9.5 & $\begin{array}{c}12.71 \\
(36.3 \%)\end{array}$ & $\begin{array}{c}13.80 \\
(39.4 \%)\end{array}$ \\
\hline Property 5 & 26 & 45 & 108 & 12 & $\begin{array}{c}22.04 \\
(84.7 \%) \\
\end{array}$ & $\begin{array}{c}19.426 \\
(74.7 \%) \\
\end{array}$ \\
\hline Property 6 & 20 & 45 & 66 & 7 & $\begin{array}{c}9.08 \\
(45.4 \%)\end{array}$ & $\begin{array}{l}12.20 \\
(61 \%)\end{array}$ \\
\hline Property 7 & 65 & 45 & 78 & 14.5 & $\begin{array}{c}29.17 \\
(44.9 \%) \\
\end{array}$ & $\begin{array}{c}20.61 \\
(31.7 \%) \\
\end{array}$ \\
\hline Property 8 & 55 & 45 & 82 & 15.5 & $\begin{array}{c}27.17 \\
(49.4 \%)\end{array}$ & $\begin{array}{c}20.51 \\
(37.3 \%)\end{array}$ \\
\hline Property 9 & 180 & 45 & 690 & 58.50 & $\begin{array}{c}75.48 \\
(41.9 \%)\end{array}$ & $\begin{array}{c}111.25 \\
(61.8 \%)\end{array}$ \\
\hline Property 10 & 2.5 & 45 & 8.80 & 0.5 & $\begin{array}{c}0.87 \\
(34.8 \%)\end{array}$ & $\begin{array}{c}1.40 \\
(56 \%)\end{array}$ \\
\hline Property 11 & 3 & 45 & 11.50 & 1.15 & $\begin{array}{c}1.71 \\
(57 \%)\end{array}$ & $\begin{array}{c}2.30 \\
(76.7 \%)\end{array}$ \\
\hline Property 12 & 52 & 45 & 117.50 & 24.5 & $\begin{array}{c}24.12 \\
(46.4 \%)\end{array}$ & $\begin{array}{l}29.64 \\
(57 \%)\end{array}$ \\
\hline
\end{tabular}


Table 3. Cumulative Margins of Error among 45 Valuers in Lagos

\begin{tabular}{|c|c|c|c|c|c|c|c|c|c|c|c|c|c|c|}
\hline \multirow{3}{*}{$\begin{array}{c}\text { Margin of } \\
\text { error } \\
(\%)\end{array}$} & \multicolumn{12}{|c|}{ Properties } & \multirow{3}{*}{$\begin{array}{l}\text { Total } \\
(540)\end{array}$} & \multirow{3}{*}{$\%$} \\
\hline & 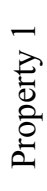 & 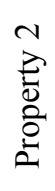 & 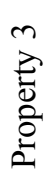 & 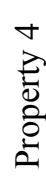 & $\begin{array}{l}n \\
\text { 总 } \\
\stackrel{0}{0} \\
0 \\
0\end{array}$ & 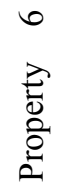 & 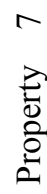 & $\begin{array}{l}\infty \\
\underset{0}{0} \\
\stackrel{0}{0} \\
0 \\
0\end{array}$ & $\begin{array}{l}a \\
\text { 完 } \\
0 \\
0 \\
0\end{array}$ & 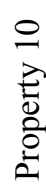 & $\begin{array}{l}\text { 二 } \\
\text { 吾 } \\
0 \\
0 \\
0\end{array}$ & 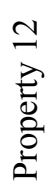 & & \\
\hline & \multicolumn{12}{|c|}{ Number of valuations within the margin of error } & & \\
\hline $0 *$ & 2 & 1 & 2 & 2 & 2 & 4 & - & 1 & 1 & 5 & 4 & - & 24 & 4.4 \\
\hline \pm 5 & 4 & 1 & 7 & 2 & 1 & 1 & 1 & - & 1 & 1 & - & 2 & 45 & 8.3 \\
\hline \pm 10 & 2 & 3 & 6 & 3 & 2 & 4 & - & 3 & 7 & 2 & 5 & - & 82 & 15.2 \\
\hline \pm 15 & 2 & 3 & 8 & 4 & - & - & 2 & 1 & 4 & 3 & - & 3 & 112 & 20.7 \\
\hline \pm 20 & 1 & 1 & 5 & 1 & - & 1 & 2 & 3 & 3 & 8 & 7 & 2 & 146 & 27.0 \\
\hline \pm 25 & 2 & 4 & 5 & 2 & 1 & 6 & 5 & 2 & 2 & -- & 1 & 4 & 180 & 33.3 \\
\hline \pm 30 & 3 & 2 & 4 & 4 & - & 1 & 4 & 3 & 1 & 4 & - & 2 & 208 & 38.5 \\
\hline \pm 35 & 2 & 2 & 4 & 5 & 3 & 1 & 2 & 1 & 3 & 1 & 2 & 2 & 237 & 44.0 \\
\hline \pm 40 & 2 & - & 1 & 1 & 1 & 2 & 2 & 5 & 6 & 3 & 1 & 3 & 264 & 49.0 \\
\hline \pm 45 & 4 & - & 1 & 4 & - & - & 1 & 2 & 1 & - & - & 2 & 279 & 51.7 \\
\hline \pm 50 & 4 & 3 & - & 3 & 3 & 4 & 4 & 1 & - & 1 & 3 & 4 & 309 & 57.2 \\
\hline $\begin{array}{l}\text { Outside } \\
\pm 50\end{array}$ & 17 & 25 & 2 & 14 & 32 & 21 & 22 & 23 & 16 & 17 & 22 & 21 & 540 & 100 \\
\hline
\end{tabular}

* Where Valuation Estimates Equal Sale Prices of Properties 
Table 4. Analysis of Valuation Variances in terms of Range of Values Amongst the Forty Five (45) Valuers Involved in the Valuation of Twelve Properties

\begin{tabular}{|c|c|c|c|c|c|c|c|c|c|c|c|c|c|}
\hline \multirow[t]{2}{*}{$\mathbf{S} / \mathbf{N}$} & \multirow[t]{2}{*}{ Valuers } & \multicolumn{12}{|c|}{ Properties } \\
\hline & & 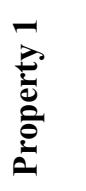 & 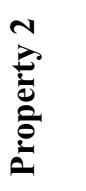 & 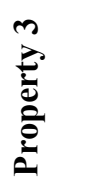 & $\begin{array}{l}+ \\
\stackrel{0}{0} \\
\stackrel{0}{0} \\
\stackrel{0}{0}\end{array}$ & 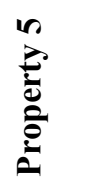 & 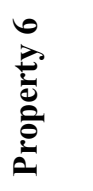 & 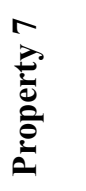 & 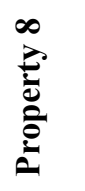 & 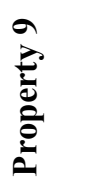 & 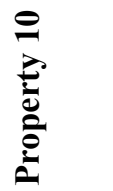 & 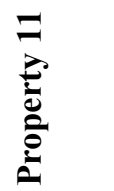 & 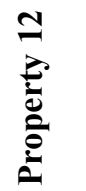 \\
\hline & & \multicolumn{12}{|c|}{$\begin{array}{c}\text { Differences between Sale Prices and Valuation Estimates of the } 12 \text { Properties Valued by } \\
\text { the } 45 \text { Valuers in millions of Naira }\end{array}$} \\
\hline 1 & 1 & $15 \mathrm{~m}$ & 35 & -75 & 2 & 8 & 10 & 12 & -22 & -58 & -20 & -25 & 60 \\
\hline 2 & 2 & -225 & -15 & 6 & -8 & -46 & -25 & -62 & -105 & 67 & -20 & -17 & 71 \\
\hline 3 & 3 & -80 & -75 & -83 & -15 & -85 & -40 & 3 & -31 & -67 & 32 & 17 & 86 \\
\hline 4 & 4 & -3 & 55 & -8 & 12 & 54 & 55 & -28 & 7 & 36 & 28 & 0 & 69 \\
\hline 5 & 5 & 25 & -400 & -900 & -65 & -362 & -275 & -31 & $\begin{array}{l}-64 \\
\end{array}$ & 61 & -300 & -367 & 13 \\
\hline 6 & 6 & 32 & -110 & -94 & -27 & 0 & -50 & -54 & -18 & -11 & 0 & -67 & 42 \\
\hline 7 & 7 & 28 & -100 & -178 & -20 & -38 & 0 & -23 & -27 & -36 & 28 & -83 & 73 \\
\hline 8 & 8 & 3 & -50 & -144 & -30 & -8 & -25 & -17 & -36 & -14 & 52 & -33 & 65 \\
\hline 9 & 9 & 43 & -25 & -39 & -35 & -131 & -30 & -29 & -9 & 0 & -12 & 10 & 13 \\
\hline 10 & 10 & -3 & 0 & -150 & -11 & -73 & 10 & -46 & -82 & 36 & -100 & -20 & 81 \\
\hline 11 & 11 & -50 & 25 & -189 & -15 & 23 & 25 & -69 & -109 & -22 & -40 & -8 & 71 \\
\hline 12 & 12 & -28 & 10 & -44 & -10 & -92 & 35 & -26 & -38 & -39 & -60 & -117 & -17 \\
\hline 13 & 13 & 8 & -150 & -67 & 2 & -73 & 0 & -48 & -55 & -69 & -20 & -67 & 52 \\
\hline 14 & 14 & 0 & -35 & 0 & 0 & -112 & -5 & -85 & 9 & -39 & -8 & -7 & 69 \\
\hline 15 & 15 & -13 & 5 & -178 & -5 & -35 & -75 & -54 & -18 & 34 & -140 & -40 & 71 \\
\hline 16 & 16 & -75 & -30 & -150 & -12 & -112 & -60 & -42 & -118 & 44 & -4 & -150 & 4 \\
\hline 17 & 17 & $\begin{array}{l}-83 \\
\end{array}$ & 20 & -3 & -17 & -150 & -50 & $\begin{array}{l}-77 \\
\end{array}$ & 0 & -8 & 0 & -107 & 12 \\
\hline 18 & 18 & -153 & 50 & -44 & -12 & -85 & -25 & -108 & $\begin{array}{l}-13 \\
\end{array}$ & -17 & -80 & 10 & 46 \\
\hline 19 & 19 & -125 & 30 & 14 & -21 & -100 & $\begin{array}{l}-60 \\
\end{array}$ & -92 & -18 & -75 & -20 & 0 & -48 \\
\hline 20 & 20 & -118 & -75 & 44 & -1 & -138 & -75 & $\begin{array}{l}-57 \\
\end{array}$ & -36 & -94 & -20 & -50 & 67 \\
\hline 21 & 21 & -90 & -60 & 22 & 5 & -162 & -50 & $\begin{array}{l}-54 \\
\end{array}$ & -45 & -317 & -48 & -83 & 4 \\
\hline 22 & 22 & -43 & -13 & $\begin{array}{l}-94 \\
\end{array}$ & -10 & -177 & -100 & -88 & $\begin{array}{l}-67 \\
\end{array}$ & -67 & 0 & -167 & -25 \\
\hline 23 & 23 & -93 & -150 & -81 & 0 & -150 & -40 & -23 & -85 & -6 & 28 & -77 & 69 \\
\hline 24 & 24 & -100 & -65 & -25 & -7 & -81 & -25 & -46 & $\begin{array}{l}-82 \\
\end{array}$ & $\begin{array}{l}-57 \\
\end{array}$ & 20 & -50 & 81 \\
\hline 25 & 25 & -43 & -100 & -178 & -21 & -46 & 0 & -66 & -49 & -25 & 12 & -17 & 85 \\
\hline 26 & 26 & -58 & -25 & -83 & -27 & -265 & -110 & -72 & -56 & -19 & 0 & 17 & -25 \\
\hline 27 & 27 & -65 & -70 & -122 & -8 & $\begin{array}{l}-77 \\
\end{array}$ & -225 & -92 & -73 & 52 & -20 & -67 & 38 \\
\hline 28 & 28 & -38 & -200 & -39 & -18 & -92 & -60 & -38 & $\begin{array}{l}-89 \\
\end{array}$ & -9 & -100 & 0 & 38 \\
\hline 29 & 29 & 8 & -110 & -89 & -25 & -131 & -75 & -62 & -100 & -53 & -60 & -20 & 71 \\
\hline 30 & 30 & -105 & -175 & -233 & -28 & -69 & -100 & -108 & -55 & -67 & -28 & 8 & 17 \\
\hline 31 & 31 & -35 & -300 & -133 & -15 & -104 & -10 & $\begin{array}{l}-92 \\
\end{array}$ & -36 & $\begin{array}{l}-78 \\
\end{array}$ & -12 & 0 & $\begin{array}{l}-38 \\
\end{array}$ \\
\hline 32 & 32 & -100 & 10 & -206 & -20 & 0 & -25 & -71 & -82 & 31 & -40 & 17 & -35 \\
\hline 33 & 33 & $\begin{array}{l}-63 \\
\end{array}$ & -25 & -344 & -10 & -35 & $\begin{array}{l}-50 \\
\end{array}$ & -54 & $\begin{array}{l}-55 \\
\end{array}$ & -28 & 0 & -33 & 62 \\
\hline 34 & 34 & -28 & -13 & 0 & -5 & -85 & -65 & -57 & -84 & -83 & -20 & -50 & -83 \\
\hline 35 & 35 & -83 & -135 & -39 & -1 & 4 & 10 & -48 & -64 & -4 & -60 & -150 & -46 \\
\hline 36 & 36 & -60 & $\begin{array}{l}-50 \\
\end{array}$ & -25 & 10 & -100 & 0 & -23 & -109 & 31 & -8 & -233 & -140 \\
\hline 36 & 36 & 0 & -75 & -161 & 5 & -142 & $\begin{array}{l}-70 \\
\end{array}$ & -26 & -122 & $\begin{array}{l}-39 \\
\end{array}$ & -40 & -117 & -121 \\
\hline 38 & 38 & 45 & 8 & -67 & -11 & -173 & 20 & -15 & -91 & -72 & -60 & -67 & -25 \\
\hline 39 & 39 & -18 & $\begin{array}{l}-63 \\
\end{array}$ & $\begin{array}{l}-69 \\
\end{array}$ & -12.5 & -48 & -62.5 & $\begin{array}{l}-19 \\
\end{array}$ & -23 & -7 & -500 & -417 & -24 \\
\hline 40 & 40 & 50 & -125 & -139 & -25 & -96 & -125 & -38 & -45 & -14 & -1000 & -833 & -48 \\
\hline 41 & 41 & -25 & -80 & -89 & -16 & -62 & -80 & -25 & -29 & -9 & -640 & -533 & -31 \\
\hline 42 & 42 & 38 & -110 & -122 & -22 & -85 & -110 & -34 & -40 & -12 & -880 & -733 & -42 \\
\hline 43 & 43 & -48 & -75 & -83 & -15 & -58 & -75 & -23 & -27 & -8 & -600 & -500 & -29 \\
\hline 44 & 44 & -4 & -150 & -133 & -3 & -150 & -65 & -85 & -91 & -17 & -1200 & -1000 & -58 \\
\hline 45 & 45 & -50 & -250 & -94 & -17 & -35 & -130 & -108 & -55 & 8 & 600 & 500 & 29 \\
\hline
\end{tabular}




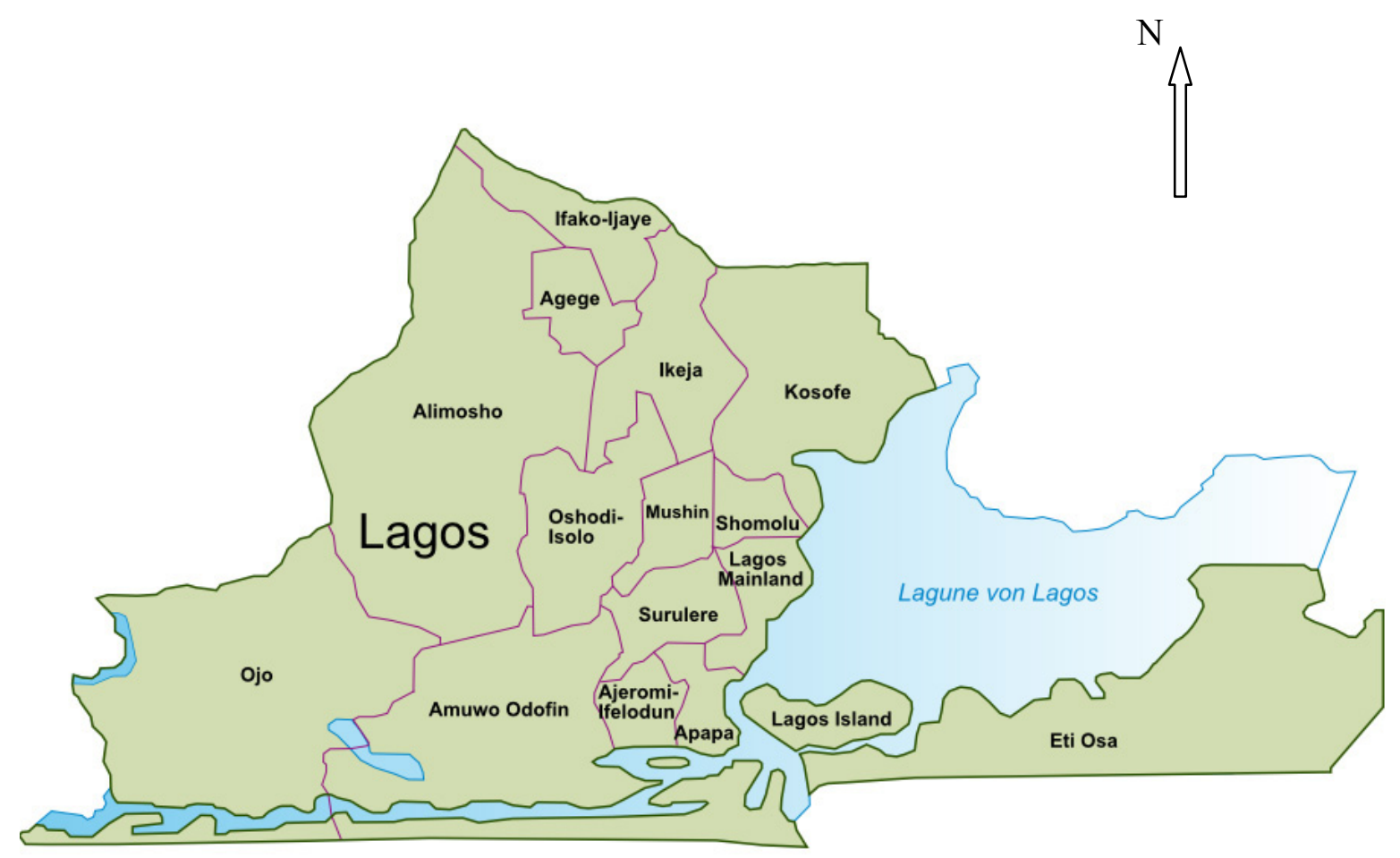

Figure 1. Map of Metropolitan Lagos

Source: Lagos State Ministry of Information 